\title{
EFEKTIVITAS PELATIHAN BUNYI HURUF DALAM MENINGKATKAN KEMAMPUAN MEMBACA AWAL SISWA SEKOLAH DASAR
}

\author{
Beatrix Carnatia Sanoe ${ }^{1}$, Sri Tiatri ${ }^{2}$, Soemiarti Patmonodewo ${ }^{3}$ \\ ${ }^{I}$ Magister Psikologi, Universitas Tarumanagara Jakarta \\ Email : beatrix.717171030@stu.untar.ac.id \\ ${ }^{2}$ Program Studi Fakultas Psikologi, Universitas Tarumanagara Jakarta \\ Email : sri.tiatri@untar.ac.id
}

Masuk : 23-09-2019, revisi: 25-11-2019 diterima untuk diterbitkan : 26-11-2019

\begin{abstract}
ABSTRAK
Penelitian ini bertujuan untuk mengetahui Apakah pelatihan bunyi huruf efektif dapat meningkatkan kemampuan membaca permulaan pada Siswa kelas 1 Sekolah Dasar. Pelatihan Bunyi Huruf ini mengacu pada teori Phonological Awareness dari Torgessen dan Wagner (1998) Phonological Awarenes adalah sensitivitas atau kesadaran eksplisit seseorang yang meliputi kemampuan mendengar, melihat, memikirkan atau memanipulasi struktur bunyi dari kata-kata dalam bahasanya. Subyek dalam penelitian ini sebanyak 12 siswa kelas 1 SD yang belum lancar membaca. Siswa tersebut dibagi menjadi 2 kelompok yaitu kelompok kontrol dan kelompok eksperimen. Alat pengumpulan data yang digunakan sebagai 1. yang pada pre-test dan post-test adalah EGRA (Early Grade Reading Assessment). Pelatihan Bunyi Huruf dilakukan sebanyak 8 kali pertemuan, dan hasil penelitian menunjukkan adanya peningkatan skor kemampuan membaca yang sangat signifikan pada kelompok eksperimen setelah diberikan pelatihan bunyi huruf. Disimpulkan bahwa pelatihan bunyi huruf terbukti efektif dalam meningkatkan kemampuan siswa sekolah dasar.
\end{abstract}

Kata kunci: pelatihan bunyi huruf, kemampuan membaca awal, siswa sekolah dasar

\begin{abstract}
This study aims to find out whether effective letter sound training can improve initial reading skills in Grade 1 Elementary School students. This Letter Sound Training refers to the Phonological Awareness theory of Torgessen and Wagner (1998) Phonological Awareness is the sensitivity or explicit awareness of a person which includes the ability to hear, see, think or manipulate the sound structure of words in the language. The subjects in this study were 12 grade 1 elementary school students who had not read fluently. The students were divided into 2 groups, namely the control group and the experimental group. The data collection tool used as a test at the pre-test and post-test was EGRA (Early Grade Reading Assessment). Letter Sounding Training was conducted in 8 meetings, and the results of the study showed a very significant increase in the reading ability score in the experimental group after being given letter sound training. It was concluded that letter sound training proved effective in improving the ability of elementary school students.
\end{abstract}

Keywords: letter sounding training, early reading ability, elementary school students

\section{PENDAHULUAN}

\section{Latar Belakang}

Membaca permulaan merupakan tahapan proses belajar membaca bagi siswa sekolah dasar kelas awal. Pada tahapan ini siswa akan memperoleh kemampuan dan menguasai teknikteknik membaca dan menangkap isi bacaan dengan baik. Membaca adalah kemampuan terpenting yang harus dipelajari pada masa kanak-kanak, Turkeltaub et al. (2005). Hal serupa dikemukakan oleh Burns et al. (Rahim, 2008) yang mengatakan bahwa kemampuan membaca merupakan sesuatu yang vital dalam suatu masyarakat terpelajar, karena aktivitas belajar pada anak dimulai dari bagaimana individu membaca, dan proses membaca buku akan sangat dipentingkan bagi anak untuk kehidupan mendatang. Jika terjadi permasalahan pada kemampuan membaca yang merupakan bagian dari kemahiran berbahasa, maka akan berdampak pada proses belajar yang lain.

Dampak dari kesulitan membaca seringkali sudah terdeksi sejak awal masuk sekolah. Namun banyak guru yang ditemui masih belum memberikan perhatian khusus pada siswa 
siswi yang belum dapat membaca di kelasnya. Gejala-gejala awal siswa yang mengalami kesulitan seringkali dianggap masih wajar. Hal ini tentunya sangat disayangkan, kemampuan siswa seharusnya dapat berkembang secara optimal jika guru dapat memperhatikan dan mengetahui kesulitan yang dialami oleh siswa di kelasnya (Mulyasa, 2006). Dibutuhkan pengetahuan tentang kesiapan awal anak anak dalam belajar membaca permulaan.

Sebelum proses belajar membaca, maka dasar-dasar kemampuan membaca serta kesiapan membaca perlu dikuasai anak terlebih dahulu (Aulia, 2011). Hal ini dilakukan agar kita mengetahui apakah anak sudah siap dalam proses tersebut, adapun kemampuan dalam kesiapan membaca yang perlu dikembangkan adalah bahwa anak memiliki kemampuan membedakan auditorial; kemampuan diskrimasi visual yakni anak bisa membedakan berbagai macam huruf yang ada; kemampuan membuat hubungan suara dan simbol yang menandainya; kemampuan perceptual motoris; kemampuan bahasa lisan; membangun sebuah latar belakang pengalaman; interprestasi gambar; progresi dari kiri ke kanan; kemampuan merangkai; penggunaan bahasa mulut; pengenalan melihat kata; lateralisasi; koordinasi gerak.

Salah satu contoh siswa yang belum bisa membaca ditemukan peneliti di salah satu sekolah dasar negeri di Jakarta Barat, Siswa bernama MF berusia 7 tahun 5 bulan, belum mampu mengucapkan dan mengenal huruf vokal dan huruf konsonan dengan lancar. Beberapa huruf yang belum mampu diucapkan atau diketahui oleh MF yaitu pada huruf vokal seperti huruf "e", sedangkan pada huruf konsonan seperti pada huruf "m, c, b, d, l, j, dan g". MF juga belum mampu mengeja suku kata sederhana yang terdiri dari satu huruf konsonan dan satu huruf vokal misalnya pada suku kata "ba" yang terdiri dari huruf"b" dan "a", bahkan dalam pengucapan huruf "b" dan "d" masih sering terbalik balik walaupun sudah diberitahu. Pemaparan tersebut membuktikan bahwa kemampuan MF dalam membaca permulaan masih kurang berkembang. Karena masih banyak huruf yang belum mampu MF ucapkan, maka MF akan mengalami kesulitan pada saat disuruh mengeja suku kata sederhana karena pengetahuan MF tentang huruf masih sangat minim. Hal ini dapat dikatakan MF masih belum mampu dalam membaca permulaan.

Membaca permulaan di sekolah dasar merupakan salah satu aspek yang sangat penting sebab hasilnya akan menjadi landasan untuk memahami ilmu-ilmu yang amat luas, lebih khusus lagi untuk pengajaran bahasa Indonesia (Dardjowidjojo, 1995). Oleh karena itu, penyiapan peningkatan kesadaran fonologis pada anak usia sekolah dasar menjadi sesuatu yang amat bermanfaat bagi mereka pada saat membaca permulaan. Seperti dijelaskan Dardjowidjojo (1995) bahwa keterampilan membaca permulaan merupakan salah satu kunci keberhasilan karena dengan cara seperti itu para siswa akan lebih mampu menggali informasi dari berbagai sumber tulisan.

Penelitian menunjukkan bahwa kebanyakan anak yang mengalami kesulitan membaca adalah adanya kelemahan pada keterampilan fonologi (Marshall, 2001), padahal kesadaran fonologi merupakan prediktor terhadap kemampuan baca anak. Oleh karena itu, salah satu stimulus yang bisa diberikan kepada anak yang mengalami kesulitan membaca permulaan yaitu kesadaran fonologi. Sejumlah penelitian lainnya menunjukkan bahwa kemampuan membaca awal atau tingkat dasar dapat dikuasai anak melalui pelatihan atau proses belajar yang menggunakan asosiasi bunyi dan simbol (Bryant dalam Parwanto 2005). Apabila kepekaan anak terhadap hubungan tersebut tidak berkembang, hal ini diyakini menjadi penyebab kesulitan membaca karena menghambat kemampuan pengkodean (decoding). 
Pada wawancara lanjutan yang dilakukan oleh peneliti kepada guru guru kelas 1, mengatakan bahwa metode yang diajarkan kepada murid murid mereka memang beragam, ada yang menggunakan metode SAS, metode Eja, dan metode Global. Guru guru tersebut mengatakan masih belum menemukan metode mana yang paling tepat agar murid murid mereka dapat cepat membaca. Dikeluhkan oleh salah seorang guru kelas satu di sekolah tersebut, bahwa hampir setengahnya bahkan lebih dari murid muridnya tersebut belum bisa membaca bahkan mereka itu masih buta huruf.

Dari uraian di atas dipaparkan ada banyak metode dalam membaca yang telah diteliti. Pentingnya kesadaran fonologi dalam membaca, menjadi hal yang menarik untuk diteliti lebih dalam. Dalam penelitian ini mengapa saya tertarik melakukan intervensi pelatihan bunyi huruf dari kesadaran fonologi dikarenakan hasil wawancara dengan guru di sekolah $\mathrm{X}$ tersebut masih kebingungan tentang metode apa yang tepat untuk mengajarkan siswa siswinya dalam membaca sementara banyak penelitian di luar negeri menekankan pentingnya kesadaran Fonologi dalam mempersiapkan anak untuk ketrampilan membacanya.

Penelitian tentang kesadaran Fonologi belum banyak diteliti di Indonesia. Berdasarkan itulah penelitian ingin melakukan penelitian pada siswa kelas 1 yang belum dapat membaca dengan memberikan pelatihan bunyi huruf guna meningkatkan kemampuan membacanya.

\section{METODE}

\section{Partisipan dan Prosedur Penelitian}

Partisipan pada penelitian ini adalah siswa kelas 1 Sekolah Dasar Negeri di Jakarta Barat. Rentang usia partisipan berada di rentang usia antara enam sampai tujuh setengah tahun. Partisipan terdiri dari enam siswa Perempuan dan tujuh siswa laki laki, lalu partisipan dibagi menjadi dua kelompok yaitu kelompok Eksperimen dan kelompok Kontrol. Pembagian kelompok ditentukan berdasarkan referensi guru, kemampuan membaca dan IQ yang dimiliki oleh anak sehingga menjadi kelompok yang sebanding.

Pada desain ini peneliti melakukan lakukan pretest awal setalah itu menentukan kelompok eksperimen (O1) dan kelompok kontrol (O2), melakukan prates untuk kedua kelompok dengan maksud untuk mengetahui homogenitas dan normalitas kedua kelompok, melakukan perlakuan eksperimen (X) yang dalam penelitian ini adalah metode Pelatihan bunyi Huruf hanya pada kelompok (O1), dan kemudia melakukan post test untuk mengukur perbedaan antara dua kelompok. Keberhasilan treatment ditentukan dengan membandingkan nilai pretest dan nilai post-test.

Prosedur eksperimen ini dilakukan dengan langkah-langkah sebagai berikut : Pertama, Tahap persiapan, meliputi: a) Perancangan penelitian, b) Studi literature, c) Pembuatan media pembelajaran dan instrumen penelitian, d) Validasi media pembelajaran dan instrument penelitian. Kedua, Tahap pelaksanaan penelitian, meliputi: a) Pengelompokkan sampel pada satu kelas penelitian siswa, b) Melaksanakan pre-test untuk mengetahui kondisi kemampuan membaca, c) Menggunakan pelatihan bunyi huruf. Kepada kelompok eksperimen sebanyak 8 kali pertemuan. Kegiatan tersebut dilakukan pada jam sekolah, siswa belajar bersama penelliti di kelas terpisah selama 35 menit dalam setiap sesinya. Media pembelajaran yang digunakan adalah video, flashcard, Sedangkan pelatihan bunyi huruf menekankan pada aktifitas kesadaran perkataan, kesadaran suku kata, kesadaran fonim, manipulasi fonim, kesadaran rima, dan penghasil rima dari kesadaran Fonologi. Ketiga, Pemberian post-test 
untuk mengetahui kemampuan membaca siswa setelah diberikan treatment. Keempat, Pengolahan dan analisis data. Kelima, Menyimpulkan hasil penelitian Prosedur penelitian diatas disusun dengan alur yang sistematis.

\section{Pengukuran/Instrument Penelitian}

Instrumen dalam penelitian ini digunakan oleh peneliti sebagai Pretest dan postest adalah Early Grade Reading Assessment (EGRA) dan Curriculum Based dari fiksi dan non-fiksi mata pelajaran kurikulum 2013. Instrumen EGRA terdiri dari berbagai subtugas yang dirancang untuk menilai keterampilan membaca dasar yang sangat penting untuk menjadi pembaca yang fasih. EGRA dirancang untuk mengukur keterampilan dasar yang harus dimiliki seorang anak untuk akhirnya dapat membaca dengan lancar. Keterampilan dasar untuk membaca ini adalah pengenalan huruf, membaca kata, dan bunyi awal. Instrument tersebut diberikan kepada partisipan terdiri atas : a) bagian kata pengantar b) bagian panduan dan c) bagian alat ukur. Ketiga hal tersebut disampaikan dalam bentuk verbal.

Pengukuran Efektivitas Membaca terdiri dari tiga indikator. Indikator tersebut adalah pengenalan huruf, membaca kata, bunyi awal. Pengukuran tersebut dibagi menjadi dua kali yaitu saat pre-test dan post-test. Semakin tinggi skor pada tiga indikator tersebut maka berarti subjek memiliki kemampuan yang baik untuk pengenalan huruf, membaca kata, maupun memahami bunyi awal. Pada periode pre-test koefisien Internal consistency reliability dimensi ini adalah 0,686 dan tidak ada indikator yang terbuang karena semua telah memiliki nilai $>0,2$

\section{Rancangan Penyusunan Modul Eksperimen}

Penyusunan modul dalam penelitian eksperimen berdasarkan 8 aktifitas untuk mengembangkan kesadaran fonologis. Kedelapan aktifitas tersebut diantaranya adalah: Mengidentifikasi bunyi huruf pertama dan terakhir dan suara dalam kata-kata, daftar katakata mulai dengan bunyi yang sama, menghitung bunyi dalam kata-kata, Katakan yang mana dari tiga kata memiliki suara yang umum, Gabungkan 2-4 suara untuk membuat kata, Pemisahan kata menjadi 3- 4 fonem, Memanipulasi suku kata (menghapus, mengganti, membalikkan), Memanipulasi bunyi dalam kata, Memanipulasi huruf untuk membuat katakata baru.

\section{Rancangan Kegiatan Intervensi}

Berikut adalah rancangan kegiatan Intervensi yang disusun sebanyak 8 sesi dengan rincian sebagai berikut:

\begin{tabular}{|c|c|c|c|c|}
\hline Sesi & Pelatihan & Materi & Waktu & Alat yang digunakan \\
\hline 1 & \begin{tabular}{l}
\multicolumn{3}{l}{ Mengidentifikasi } \\
bunyi \\
pertama huruf \\
terakhir dan suara \\
dalam kata-kata
\end{tabular} & $\begin{array}{lr}\text { Aktifitas } & \text { yang } \\
\text { dilakukan } & \text { dalam } \\
\text { penelitian ini adalah } \\
\text { menebak suara apa } \\
\text { yang diperdengarkan } \\
\text { oleh peneliti. Suara } \\
\text { suara } \\
\text { diperdengarkan adalah } \\
\text { suara berbagai suara } \\
\text { binatang dari }\end{array}$ & $\begin{array}{l}35 \\
\text { Menit }\end{array}$ & $\begin{array}{l}\text { Aplikasi } \\
\text { sound }\end{array}$ \\
\hline 2 & kata-kata & mencari kata yang & 35 & Mengunakan \\
\hline
\end{tabular}




\begin{tabular}{|c|c|c|c|c|}
\hline & $\begin{array}{l}\text { mulai dengan bunyi } \\
\text { yang sama }\end{array}$ & $\begin{array}{l}\text { seirama atau yang } \\
\text { tidak seirama }\end{array}$ & Menit & $\begin{array}{l}\text { bergambar } \\
\text { Flashcards. }\end{array}$ \\
\hline 3 & $\begin{array}{l}\text { Menghitung bunyi } \\
\text { dalam kata-kata }\end{array}$ & $\begin{array}{l}\text { menghitung jumlah } \\
\text { suara yang ada dalam } \\
\text { kata }\end{array}$ & $\begin{array}{l}35 \\
\text { Menit }\end{array}$ & $\begin{array}{l}\text { bottle cup yang } \\
\text { diberi tulisan huruf } \\
\text { diatasnya }\end{array}$ \\
\hline 4 & Katakan yang mana & melatih kemampuan & 35 & Mengunakan \\
\hline & $\begin{array}{lr}\text { dari tiga } & \text { kata } \\
\text { memiliki } & \text { suara } \\
\text { yang umum } & \end{array}$ & $\begin{array}{l}\text { dalam memilih } 3 \\
\text { bunyi huruf yang } \\
\text { memiliki arti }\end{array}$ & Menit & $\begin{array}{l}\text { bergambar } \\
\text { Flashcards. }\end{array}$ \\
\hline 5 & $\begin{array}{lr}\text { Gabungkan } & 2-4 \\
\text { suara untuk } & \\
\text { membuat kata }\end{array}$ & $\begin{array}{l}\text { menggabungkan } 2 \\
\text { sampai } 4 \text { bunyi huruf } \\
\text { menjadi satu kata }\end{array}$ & $\begin{array}{l}35 \\
\text { Menit }\end{array}$ & Kalender Huruf \\
\hline 6 & $\begin{array}{l}\text { Pemisahan kata } \\
\text { menjadi 3- } 4 \text { fonem }\end{array}$ & $\begin{array}{l}\text { memenggal kata } \\
\text { menjadi bebrapa suku } \\
\text { kata }\end{array}$ & $\begin{array}{l}35 \\
\text { Menit }\end{array}$ & $\begin{array}{l}\text { Whiteboard, Spidol, } \\
\text { dan bottle cap }\end{array}$ \\
\hline 7 & $\begin{array}{l}\text { Memanipulasi suku } \\
\text { kata (menghapus, } \\
\text { mengganti, } \\
\text { membalikkan) }\end{array}$ & $\begin{array}{l}\text { memanipulasi kata } \\
\text { dengan } \\
\text { menghilangkan } \\
\text { menambahkan atau } \\
\text { memindahkan bunyi } \\
\text { huruf }\end{array}$ & $\begin{array}{l}35 \\
\text { Menit }\end{array}$ & $\begin{array}{l}\text { Whiteboard, Spidol, } \\
\text { dan bottle cap }\end{array}$ \\
\hline 8 & $\begin{array}{l}\text { Memanipulasi } \\
\text { bunyi dalam kata }\end{array}$ & $\begin{array}{l}\text { memanipulasi bunyi } \\
\text { yang berada dalam } \\
\text { kata }\end{array}$ & $\begin{array}{l}35 \\
\text { Menit }\end{array}$ & Kalender Huruf \\
\hline
\end{tabular}

\section{HASIL DAN PEMBAHASAN}

Gambaran subyek penelitian ini secara umum dapat dilihat dari berbagai hal yang dipertimbangkan menjadi data kontrol dalam penelitian. Gambaran tersebut akan dijelaskan satu per satu oleh peneliti. Berdasarkan data yang diperoleh mengenai jenis kelamin subyek penelitian dari data total 12 orang subyek penelitian, subyek yang berjenis kelamin laki-laki berjumlah 4 orang $(33.3 \%)$, subyek yang berjenis kelamin perempuan berjumlah 8 orang $(66.7 \%)$. Untuk penjelasan detailnya dapat dilihat pada tabel 1

Tabel 1. Gambaran Subyek Berdasarkan Jenis Kelamin

\begin{tabular}{ccc}
\hline Jenis Kelamin & Frekuensi & Persentase \\
\hline Laki-laki & 4 & 33.3 \\
Perempuan & 8 & 66.7 \\
Total & 12 & 100 \\
\hline
\end{tabular}

Gambaran data selanjutnya adalah berdasarkan data yang diperoleh mengenai kelompok subyek penelitian dari data total 12 orang subyek penelitian, subyek yang ditempatkan pada kelompok kontrol berjumlah 6 orang $(50 \%)$, subyek yang ditempatkan pada kelompok eksperimen 6 orang $(50 \%)$. Untuk penjelasan detailnya dapat dilihat pada tabel 2.

Tabel 2. Gambaran Subyek Berdasarkan Kelompok

\begin{tabular}{ccc}
\hline Kelompok & Frekuensi & Persentase \\
\hline Eksperimen & 6 & 50.0 \\
& & \\
444 & https://doi.org/10.24912/jmishumsen.v3i2.6022
\end{tabular}




$\begin{array}{ccc}\text { Kontrol } & 6 & 50.0 \\ \text { Total } & 12 & 100\end{array}$

\section{Gambaran Data Penelitian}

Pada bagian ini akan dibahas mengenai gambaran data penelitian. Kegiatan Intervensi yang dilakukan tidak ada perbedaan dengan rancangan Intervensi. Gambaran data untuk variabel penelitian menunjukkan angka minimum adalah 0 dan maksimum 100. Skor mean variabel penelitian untuk pre test dengan nilai 29.4167 sedangkan nilai variabel untuk post test dengan nilai 53.1583 .

Tabel 3. Gambaran Data Penelitian

\begin{tabular}{ccccc}
\hline & Minimum & Maximum & Mean & SD \\
\hline Tot_Pre & 23.00 & 53.80 & 29.4167 & 9.18931 \\
Tot_Post & 23.00 & 100.00 & 53.1583 & 30.17384 \\
\hline
\end{tabular}

\section{Analisis Data Utama}

Berdasarkan data yang diperoleh, dilakukan uji perbedaan pada skor sebelum dan sesudah intervensi. Dari hasil pengolahan data diperoleh bahwa dari nilai Mean pre test $=29.4167$ dan Mean pre test $=53.1583$ diperoleh nilai $\mathrm{z}=-2,375$, dan $\mathrm{p}<0.05$. Dengan nilai tersebut maka dinyatakan ada perbedaan signifikan pada skor sebelum intervensi dan sesudah intervensi. Selain itu dari nilai Mean pre dan post maka dinyatakan adanya peningkatan skor sebelum dan sesudah intervensi. Hasil selengkapnya dapat dilihat pada tabel 4.

Tabel 4.Hasil Uji Perbedaan Skor Sebelum dan Sesudah Intervensi

\begin{tabular}{cccc}
\hline Pengujian & Mean & $\mathbf{z}$ & p \\
\hline Pre Test & 29.4167 & $-2,375$ & 0.000 \\
Post Test & 53.1583 & & \\
\hline
\end{tabular}

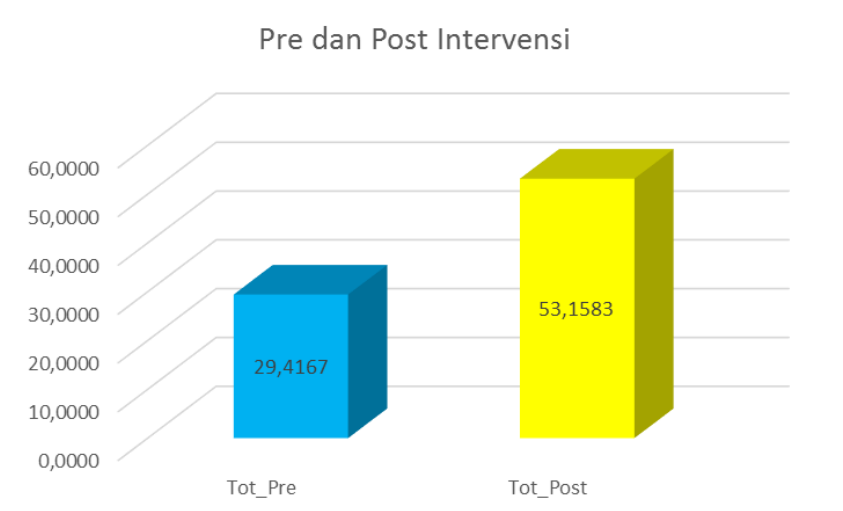

Gambar 1. Nilai Program Intervensi Periode Pre Test dan Post Test

\section{Analisis Data Tambahan}

Berdasarkan data yang diperoleh, dilakukan uji perbedaan pada skor sebelum dan sesudah intervensi dari penilaian guru sekolah. Dari hasil pengolahan data diperoleh bahwa dari nilai Mean pre test $=38,0833$ dan Mean pre test $=48,8333$ diperoleh nilai $\mathrm{z}=-1,580$, dan $\mathrm{p}>$ 0.05. Dengan nilai tersebut maka dinyatakan tidak ada perbedaan signifikan pada skor sebelum intervensi dan sesudah intervensi. Namun demikian, dari nilai Mean pre dan post maka dinyatakan adanya peningkatan skor sebelum dan sesudah intervensi pada penilaian guru di sekolah. Hasil selengkapnya dapat dilihat pada tabel 5. 
Tabel 5. Hasil Uji Perbedaan Skor Sebelum dan Sesudah Intervensi Pada Penilaian

\begin{tabular}{cccc} 
& Guru & & \\
\hline Pengujian & Mean & $\mathbf{z}$ & p \\
\hline Pre Test & 38,0833 & $-1,580$ & 0.114 \\
Post Test & 48,8333 & & \\
\hline
\end{tabular}

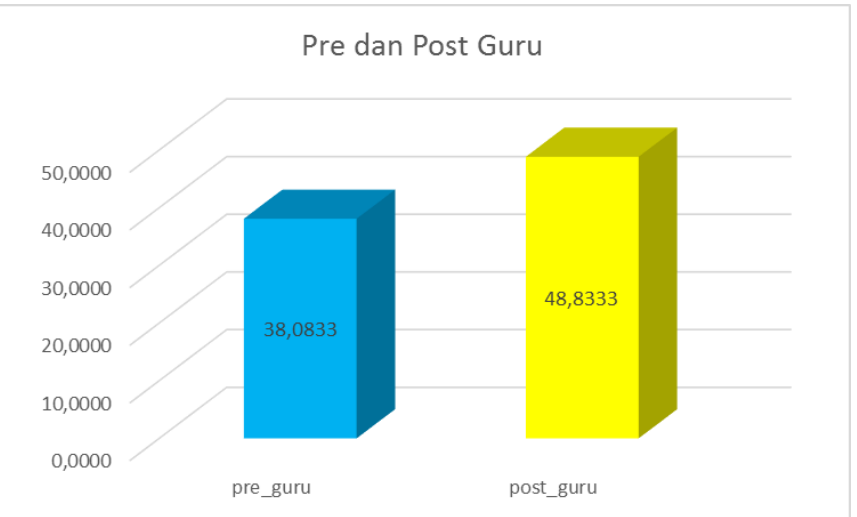

Gambar 2. Penilaian Guru Periode Pre Test dan Post Test

\section{Perbedaan Skor Pre-Test Kelompok Kontrol dan Eksperimen Program Intervensi}

Berdasarkan data yang diperoleh, dilakukan uji perbedaan pada skor pre test kelompok kontrol dan eksperimen pada program instervensi diperoleh bahwa nilai Mean Rank kelompok eksperimen $=7,83$ dan Mean Rank kelompok kontrol $=5,17$ diperoleh nilai $\mathrm{z}=-0.163$, dan $\mathrm{p}>0.05$. Dengan nilai tersebut maka dinyatakan tidak ada perbedaan signifikan pada skor kelompok kontrol dan eksperimen pada program intervensi. Hasil selengkapnya dapat dilihat pada tabel 6 .

Tabel 6. Hasil Uji Perbedaan Skor Pre Test Kelompok Kontrol dan Eksperimen Intervensi

\begin{tabular}{cccc}
\hline Pengujian & Mean & $\mathbf{Z}$ & $\mathbf{p}$ \\
\hline Eksperimen & 7,83 & 0.163 & 0.240 \\
Kontrol & 5,17 & & \\
\hline
\end{tabular}

\section{PEMBAHASAN}

Peneliti ingin membahas beberapa temuan sepanjang penelitian ini berlangsung. Pertama, berdasarkan deskripsi data tampak bahwa efektivitas perlakuan sangat mencolok dalam hasil perolehan skor pada kelompok eksperimen antara sebelum (pretest) dengan setelah (postest) pemberian perlakuan melalui pelatihan bunyi huruf dalam meningkatkan kemampuan membaca permulaan terdapat perbedaan yang signifikan. Perbedaan yang signifikan juga terdapat pada subtes yang digunakan untuk mengukur pretest dan postes diukur satu persatu, yakni membaca huruf, membedakan bunyi awal, membaca kata diukur secara tersendiri. Temuan ini menggambarkan bahwa tanpa adanya kelompok kontrol, pelatihan Bunyi Huruf efektif dalam meningkatkan kemampuan membaca pemulaan.

Kedua, berdasarkan latar belakang penelitian tampak bahwa kemampuan membaca permulaan meningkat ketika mereka diberi perlakuan secara khusus melalui pelatihan bunyi huruf. Sesuai dengan hasil-hasil studi yang dilakukan oleh (Bradley dan Bryant; Share, et.al; Vellutino dan Scanlon; William dalam Torgessen, et.al., 1989). terdahulu menunjukkan 
Keterampilan kesadaran fonologis secara berulang telah dikaitkan dalam bermacam-macam penelitian korelasional, longitudinal, dan eksperimental terhadap keberhasilan membaca pada tahap awal. Berdasarkan konsepsi-konsepsi ini dapat dirumuskan bahwa nilai kesadaran fonologis sangat membantu siswa dalam kemampuan membaca pada tahap-tahap berikutnya. Ketiga, sekalipun hasil studi eksperimen pelatihan bunyi Huruf dalam meningkatkan kemampuan membaca permulaan menunjukkan secara signifikan hasil yang efektif, namun masih dipertanyakan apakah pelatihan ini efektif pula jika diterapkan untuk populasi yang berbeda. Studi ini tidak sampai pada jawaban atas pertanyaan tersebut. Akan tetapi, jika memperhatikan hasil hasil studi terdahulu, peluang itu menjadi terbuka, yakni pelatihan ini dapat diterapkan pada populasi yang berbeda.

Keempat, teori pemrosesan informasi memiliki tiga operasi umum yaitu encoding, penyimpanan, dan pengambilan. Dalam encoding ada beberapa faktor yang mempengaruhi proses ini yaitu atensi, pemrosesan mendalam, pengulangan, dsb. Penyimpanan terdiri dari sensori memori, memori jangka pendek atau working memori, dan memori jangka panjang (simpanan). Sementara pada pengambilan terdapat dua macam yang terjadi pada proses pengambilan yaitu pemanggilan kembali dan lupa, dengan memahami teori pemrosesan informasi guru dapat menyelenggarakan proses pembelajaran yang menciptakan suasana interaktif, inspiratif, menyenangkan, memberi tantangan, memunculkan motivasi untuk berpartisipasi dalam pembelajaran, dan memberikan ruang serta kesempatan kepada peserta didik untuk berkreatifitas sesuai dengan bakat, minat, dan perkembangan fisiknya.

\section{KESIMPULAN DAN SARAN}

Penelitian ini bertujuan untuk mengetahui tentang efektivitas pelatihan bunyi Huruf dalam meningkatkan kemampuan membaca permulaan pada siswa sekolah dasar. Berdasarkan hasil analisis data, maka dapat disimpulkan bahwa pelatihan bunyi huruf terbukti meningkatkan kemampuan membaca permulaan siswa sekolah dasar, terdapat perbedaan kemampuan membaca permulaan siswa kelas satu sekolah dasar sebelum dan sesudah dilakukan pelatihan bunyi huruf. Nilai posttest lebih tinggi daripada nilai pretest. Kemampuan membaca permulaan sesudah dilakukan pembelajaran lebih baik dibandingkan dengan kemampuan membaca permulaan sebelum dilakukan pembelajaran.

Berdasarkan hasil penelitian bahwa pelatihan Bunyi Huruf efektif dalam meningkatkan kemampuan membaca pemulaan, perlu upaya penyebarluasan penerapan model pada saat awal anak masuk sekolah dasar agar mereka siap menghadapi tugas belajar membaca berikutnya dengan baik. Untuk itu, para penyusun kurikulum SD untuk kelas 1 agar memasukkan materi yang dapat menciptakan kesadaran fonologi; para penyusun buku pelajaran kelas 1 agar menyiapkan materi kesadaran fonologi terlebih dahulu sebelum tahap membaca berikutnya; para guru agar mempelajari strategi peningkatan kesadaran fonologi hasil peneitian ini agar mereka siap mengimplementasikannya di sekolah secara baik

Bagi Orang tua dapat memanfaatkan pelatinya bunyi huruf ini untuk menstimuli anak dalam perkembangan bahasanya dengan penekanan pada aspek kesadaran fonologinya, mengingat kemampuan membaca awal perlu dilatihkan sebelum memasuki usia sekolah. Selain itu kesadaran fonologi ini juga dapat digunakan sebagai deteksi dini untuk membantu anak yang mengalami kesulitan mengucapkan kata dengan tepat 


\section{Ucapan Terima Kasih (Acknowledgement)}

Penulis mengucapkan terimakasih sebesar-besarnya kepada para pemimpin, guru dan siswa SDN $X$, atas kesempatan yang diberikan kepada penulis sehingga pengambilan data, wawancara observasi terkait penelitian ini dapat terlaksana.

\section{REFERENSI}

Anderson, J.R. (1996). ACT: A Simple Theory og Complex Cognition. Amarican Psychologist.

Atkinson, R., Richard, A., \& Hilgard, E. (2000). Pengantar Psikologi. Jilid 1, Edisi 8. Penerjemah: Agus, D, Michael, A. Jakarta : Penerbit Erlangga.

Aulia, 2011 Mengajarkan Balita Anda Membaca: Revolusi Cerdas Untuk Kemampuan Anak Membaca Di Rumah. Jogjakarta: Intan Media

Baddeley, A. D. (2001). Is Working Memory Still Working?. American Psychologist.

Dale, H. S.. (2012). Learning Theories an Educational Perspective. American Psycologist

Dardjowidjojo, S. (2003) Psikolinguistik: Pengantar Pemahaman Bahasa Manusia. Jakarta

Gagne, R. M. (1985). The Conditions of Leraning. New york; Holt, Rinehart \& Windston

Mayer, R. E. (1996). Learners As Information Processors; Legacies And Limitation Of Psychology's Second Metaphor. Educational psychologist

Schmidt, R. A. (1989). Motor Control and Learning: A Behavioral Emphasis. Champaign: Human Kinetic Publishers, Inc

Torgessen, J.K., Morgan, S.T. and Davis, C. (1992). Effects of two types of phonological awareness training on word learning in kindergarten children. Journal of Educational Psychology, 84, 364-370.

Wagner, R.K. and Torgessen, J.K., 1987, The nature of phonological processing and its causal role in the acquisition of reading skills. Psychological Bulletin, 101,192-212.

Widyana, R. 1999. Efektifitas pelatihan kesadaran Fonemik dalam meningkatkan kemampuan Pra membaca anak anak Prasekolah. Tesis. Yogyakarta. Program Pasca Sarjana UGM. 